\title{
Professional Learning through a Digital Platform
}

Journal of Research in Interprofessional

Practice and

Education

Vol. 9.1

2019

\footnotetext{
a. Norwegian University of Science and Technology

b. Østfold University College

c. Western Norway University of Applied Sciences
}

\author{
Frøydis Vasset ${ }^{\mathrm{a}}, \mathbf{R N}, \mathrm{PhD}$; Siri Brynhildsen ${ }^{\mathrm{b}}, \mathbf{R N}, \mathbf{M D}$; \\ Bente Kvilhaugsvik ${ }^{\mathrm{c}}, \mathrm{RN}, \mathrm{MD}$
}

\begin{abstract}
Background: Pedagogical methods that implement mutual learning are referred to as interprofessional learning. The aim of this study was to investigate nursing, biomedical science, and social education students' experiences with interprofessional collaborative learning through a digital platform.

Method: Students from three university colleges met virtually and discussed a videotaped interprofessional case. After the project, three focus group interviews were conducted.

Findings: Three themes were identified: interprofessional collaborative learning, the use of a digital platform, and communication in virtual meetings.

Conclusions: Interprofessional discussions made students aware of both their own responsibilities and limitations and those of other professionals, in the process of creating a mutual understanding of an interprofessional case scenario. The facilitator is crucial to ensure a safe atmosphere and include all students in the communication process.
\end{abstract}

Keywords: Interprofessional learning; Nurse students; Biomedical science students; Virtual meeting

\section{Introduction}

The World Health Organization (WHO) emphasizes collaboration as fundamental to the development of the interprofessional collaborative competence of a student $[1,2]$. The WHO states that collaboration depends on the ability of an interprofessional group to solve problems, act flexibly, and include the right professions in different parts of the work process [2]. Collaboration is related to group dynamics, where group members are expected to have an ability to communicate, make appropriate assessments of a situation, and analyze various options for action [3]. The intention of interprofessional learning (IPL) in health and social studies is that students develop a common framework for their understanding and a common identity as welfare workers; factors that are emphasized as important for interprofessional collaboration [3,4]. Traditionally, professionals work easily with persons from their own profession, but not so easily across professional boundaries [4]. Therefore, IPL should be a vital part of education programs to prepare students for collaborative practice when they enter their professions.

Task collaborations between students of different professions could prevent participating individuals from developing negative stereotypes of other professions $[5,6]$. Already in 1954, Allport [6] underlined that people collaborate, learn from, 
2

Interprofessional Learning

Vasset, Brynhildsenb, \& Kvilhaugsvik

Journal of Research in Interprofessional Practice and Education

Vol. 9.1

2019 respect and appreciate participants from other professions. Research also shows that interprofessional learning affects the quality of patient care and treatment [7]. Interprofessional collaboration can also lead to a positive and safe work environment, which could affect patient safety and care in a positive way [8].

Interprofessional learning encompasses learning and requires communication and reflection to find constructive solutions to complex healthcare challenges [19-23]. Conversations are based on a specific experience. Students look deeper into parts of a situation, reflect, discuss themes, evaluate what has been learned, and plan how to use their new knowledge [24]. Joint activity and discussion can lead to more reflection $[24,25]$. Studies on interprofessional collaboration emphasize the importance of reflection regarding the need to understand the expertise of other professionals and the fact that those professions offer complementary skills [24].

However, students need some assistance in IPL. Efforts to help group participants become involved in interprofessional group discussions are called facilitation. A facilitator supports the participants in communication and reflection, and helps group members exchange ideas and find solutions they probably would not have found on their own [9]. The Norwegian Educational Ministry urges educational institutions to facilitate IPL [4]. Nevertheless, there is little information about how IPL should be conducted. Grouping students into interprofessional groups during education is important [10], but it does not automatically make them learn from, with, and about each other. Students can gain a better understanding of other professional fields and responsibilities, but only pedagogical methods that implement mutual learning are referred to as IPL [11]. To learn, it is necessary for students to interact and work together on specific issues. Indeed, IPL requires interaction between students, either physically or through computer-supported collaborative learning (CSCL). An interaction can be understood in at least three different ways: occurring between participants; occurring between different knowledge bases, ideas, arguments, and ways of thinking; or occurring between what has been discussed in the group and the larger sociocultural context [9,23]. To apply this theory, a facilitator may be useful. Facilitating a group can help group members illuminate the experiences of each student in a work situation. Facilitation can also help students to become aware of obstacles and what makes work difficult [25].

There is an ongoing discussion about when and how interprofessional collaboration should be introduced in a bachelor program [26,27]. Other challenges include geographical distance and the use of technology. Geographical distances and different curricula can provide challenges when implementing IPL. This issue is particularly difficult for university colleges with only one or two health and social education programs, because they are dependent on collaboration with other educational institutions to achieve interprofessionality [12]. Virtual learning can be helpful in this regard [28]. Virtual learning is another term for electronic learning, which can broadly be defined as the learning and training that takes place through information and communication technology. The definition of virtual meetings is the use of, and meetings, via communication technology. In a digital platform, it is possible to talk together and see each other on the computer screen [13]. This strategy could offer a 
3

Interprofessional Learning

Vasset, Brynhildsenb, \& Kvilhaugsvik
Journal of Research in Interprofessional Practice and Education solution to IPL implementation challenges, as a digital platform can be a means to overcome logistical challenges [12,14]. There is an opportunity for students to learn and develop common interprofessional knowledge through CSCL, which is collaborative learning and communication mediated through computers. The purpose of this study was to explore the experiences of nursing, social education, and biomedical science students with IPL mediated through a digital platform.

\section{IPL through a digital platform}

A digital platform provides opportunities for new ways to collaborate. Students from different educational institutions and regions can be incorporated into the same learning situations [15]. There is an increasing interest in the use of CSCL in educational institutions, although studies have also shown that it can be unclear how this kind of learning takes place or how to use such educational tools [16]. Virtual learning can be used to overcome barriers of timetabling and geographic distances. Students can learn about the roles of others, and together they can solve problems that arise in the workplace. Students working in an interprofessional workshop where CSCL was used, developed a deeper understanding of interprofessionality $[12,17]$. Other studies have found that there were no unique benefits or experiences from CSCL [18].

\section{The IPL project}

In this study, the IPL project was a collaboration between three university colleges in western (Norwegian University of Science and Technology [Campus Aalesund]), eastern (Western Norway University of Applied Sciences [Campus Stord]), and southern (Østfold University College) Norway (see Table 1). In total, 20 students from nursing, social education, and biomedical science study programs participated. The students were divided into four interprofessional groups with representatives from each of the three student professions and university colleges. A virtual classroom in a learning management system (LMS) was established. The students were instructed to watch a video of an interprofessional case. A young boy with an intellectual disability came to the office of a general practitioner to provide some blood samples. The boy's anxiety led to chaos in the laboratory, and blood samples were not taken. The student groups and facilitators discussed the case in two virtual meetings on a digital platform. The students used learning resources provided in the LMS and completed some assignments.

Table 1. Breakdown of interview focus groups

\begin{tabular}{|l|l|l|l|}
\hline Discipline & $\begin{array}{l}\text { Norwegian University of } \\
\text { Science and Technology } \\
\text { (Campus Aalesund) }\end{array}$ & $\begin{array}{l}\text { Western Norway University } \\
\text { of Applied Sciences } \\
\text { (Campus Stord) }\end{array}$ & Østfold University College \\
\hline Nursing & $\begin{array}{l}\text { Two } \\
\text { 2nd cohort }\end{array}$ & $\begin{array}{l}\text { Three } \\
\text { 3rd cohort }\end{array}$ & $\begin{array}{l}\text { Two } \\
\text { 2nd cohort }\end{array}$ \\
\hline Biomedical science & $\begin{array}{l}\text { Two } \\
\text { 1st cohort }\end{array}$ & Zero & Zero \\
\hline Social education & Zero & Zero & Zero \\
\hline
\end{tabular}




\section{JRIPE}

4

Interprofessional Learning

Vasset, Brynhildsenb, \& Kvilhaugsvik

Using the IPL project as a background, the research question was as follows: what experiences did the students in this project have with IPL through a digital platform in a collaborative study between three university colleges?

\section{Methods}

Design

The study had a qualitative design with a descriptive phenomenological approach, focusing on the meaning of the participants' statements [29]. This method can be used to find the essence of a phenomenon by starting from how the participants experience something [30]. Focus group interviews were conducted with some of the students after the IPL project period, to gather information about their experiences with IPL mediated through a digital platform.

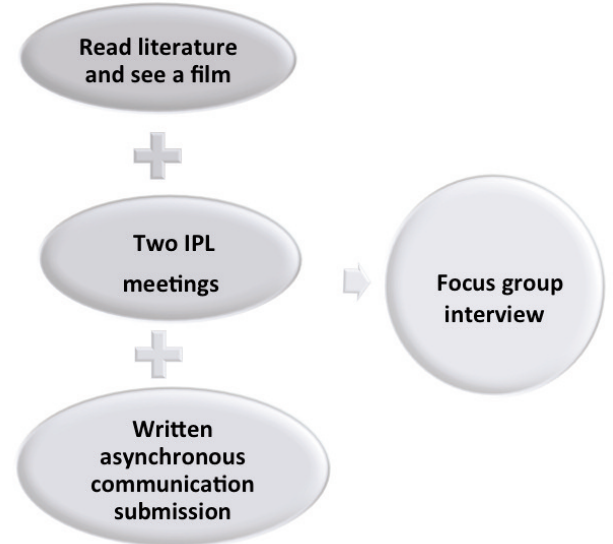

\section{Figure 1. The project program/interview}

\section{Sample}

The data were collected through three focus group interviews. All students $[N=20]$ in the IPL project were invited, and nine of these students accepted the invitation.

\section{Focus group interviews}

Focus group interviews give researchers an opportunity to gather data in a different way than individual interviews [31]. The key is to gain insight into the dynamics of interactions and to increase reflection in the discussions. A semi-structured interview guide was developed for this study. It covered the main themes used during collaboration in the virtual meetings, including students' experiences with their roles and responsibilities in the interprofessional collaboration. Finally, students were asked about the importance of interprofessional collaboration. Follow-up prompts were provided.

Three focus group interviews were conducted, one at each university college. The

Journal of Research in Interprofessional Practice and Education focus group interviews were audio recorded and lasted approximately 45 minutes each. In small groups, when the questions are not sensitive, 45 minutes can be enough to reach data saturation [31]. The interviews were transcribed verbatim, and the audiotapes were erased. After the three focus group interviews were transcribed, the data were analyzed. 
5

Interprofessional Learning

Vasset, Brynhildsenb, \& Kvilhaugsvik

Journal of Research in Interprofessional Practice and Education

Vol. 9.1

2019
Analysis

Giorgi's analysis strategy [32,33] was used to analyze the transcribed interviews. Malterud's theory [31] for systematic text coding was also used. The analysis included four steps: 1) reading the transcript several times to obtain a holistic impression, 2) identifying meaningful units, 3) abstracting the content of meaningful units into categories, and 4) summarizing the meaning of the categories into themes and subthemes and interpreting the data $[32,33]$. The analysis was an iterative but not a linear process, constantly moving back and forth through the steps. All three authors conducted the analysis of the interviews independently. Then, the themes and subthemes were compared and discussed in several research group meetings until a consensus was achieved. Finally, the themes were discussed and the raw data and the overall impression of the data were critically evaluated [30].

\section{Ethical considerations}

The study was based on the ethical standards of the Privacy Act (Ethical Standard in Public Life, Act 2000) [34]. That included written informed consent, anonymity, and confidentiality. The participants were informed that they could withdraw from the focus group interviews without any negative consequences. The Norwegian Centre for Research Data (NSD) approved the study and assigned it reference number 47906.

\section{Results}

Three main themes were identified: interprofessional collaborative learning, the use of a digital platform, and communication in virtual meetings. Direct statements from the participants are written in italics. Table 2 highlights the analysis process.

Table 2. The themes, subthemes, and some meaningful units

\begin{tabular}{|l|l|l|l|}
\hline & Themes & Subthemes & Meaningful units \\
\hline Theme 1 & $\begin{array}{l}\text { Interprofessional } \\
\text { collaborative } \\
\text { learning }\end{array}$ & $\begin{array}{l}\text { Own professional } \\
\text { role } \\
\text { Discovering other } \\
\text { professionals' roles } \\
\text { The importance of } \\
\text { collaboration }\end{array}$ & $\begin{array}{l}\text { I feel a bit like we are determined to contact other professions } \\
\text { and that we work as glue in collaborative practice. } \\
\text { Ilike to ask other professionals for advice when I see that my } \\
\text { own expertise is not sufficient. } \\
\text { We do not think so much about who we work with, and how } \\
\text { much it means to the patients that we collaborate with the } \\
\text { other individuals who also help the patient. }\end{array}$ \\
\hline Theme 2 & $\begin{array}{l}\text { The use of digital } \\
\text { platforms }\end{array}$ & $\begin{array}{l}\text { Case presentation } \\
\text { The use of digital } \\
\text { platforms }\end{array}$ & $\begin{array}{l}\text { The text can be interpreted differently. } \\
\text { It should have been stated that students are expected to be } \\
\text { active in virtual meetings. }\end{array}$ \\
\hline Theme 3 & $\begin{array}{l}\text { The facilitation of of } \\
\text { communication in } \\
\text { digital platforms }\end{array}$ & $\begin{array}{l}\text { To be prepared } \\
\text { Communication in } \\
\text { digital platform } \\
\text { Facilitation and } \\
\text { reflection }\end{array}$ & $\begin{array}{l}\text { It was okay to talk to the facilitator before the meeting started. } \\
\text { I know it was easier for me to say what I meant in the virtual } \\
\text { meeting than it might have been if everyone sat around a table. } \\
\text { It must be accepted that some students will not understand } \\
\text { questions and do not know what the facilitator is asking. }\end{array}$ \\
\hline
\end{tabular}


6

Interprofessional Learning

Vasset, Brynhildsenb, \& Kvilhaugsvik

Journal of Research in Interprofessional Practice and Education

Vol. 9.1

2019

\section{Theme 1: Interprofessional collaborative learning}

Own professional role

Students became aware of the responsibilities and limitations of their professions. The students thought that the nurses were often responsible for coordination in collaborative situations. A nursing student (N) said: I feel a bit like we are determined to contact other professions, and that we work as glue in collaborative practice.

\section{Discovering other professionals' roles}

The students said it was interesting to listen to other students describing their professional work arena. They received useful ideas for their own professional work. The students emphasized that different professionals would handle the situation in the filmed case in different ways. A nursing student $(\mathrm{N})$ said: I like to ask other professionals for advice when I see that my own expertise is not sufficient. Some students thought it was challenging to collaborate across professions, especially as these individuals were in different years of their education. A biomedical science student (B) stated: We felt a little inferior because we only were in the first year of study. However, it was obvious in the focus group interview that the other students acknowledged the participation of these individuals and listened carefully to what they had to say.

\section{The importance of collaboration}

The participants reported that they had discovered the importance of collaboration and that they needed to practice working together interprofessionally. One student (N) referred to previous experiences: We do not think so much about who we work with, and how much it means to the patients that we collaborate with the other individuals who also help the patients. The students reported that they eventually learned about the importance of collaboration in ensuring quality in patient healthcare service. A participant (B) also said: If we get a glimpse inside another profession that receives different training and see that profession from another angle, we must get a new view on healthcare.

\section{Theme 2: The use of digital platforms}

\section{Case presentation}

The students said that the filmed case was a good tool for visualizing an authentic collaborative situation. One student $(\mathrm{N})$ said: It is easier to catch on when you see it in a movie. Another student (B) said: The text can be interpreted differently. The fact that you see the body language of the participants on tape gives you more information than you can get by reading a written scenario. The students believed that the film also gave more inspiration for reflection than the text. The students recommended that educational institutions use short films in IPL.

\section{The use of digital platforms}

The students found virtual meetings on a digital platform as a good tool for IPL. Some students said they were comfortable using a digital platform when they spoke with the other students. They also emphasized that the facilitator should focus on ensuring that all students are active in the conversations. One student $(\mathrm{N})$ said: It should have been 
7

Interprofessional Learning

Vasset, Brynhildsenb, \& Kvilhaugsvik

Journal of Research in Interprofessional Practice and Education

Vol. 9.1

2019 stated that students are expected to be active in virtual meetings. Another drawback was that students identified some problems with noise and echo in the virtual meetings, mostly because some of the participants were in a library or in a vestibule.

\section{Theme 3: The facilitation of communication on digital platforms}

\section{To be prepared}

The students reported that it was of great value to have a preparatory virtual meeting with the facilitator before the IPL project started. This virtual meeting was conducted to see each other's faces and to get to know each other a little. One student (B) said: It was okay to talk to the facilitator before the meeting started. It gave me some security. Because the groups comprised students from three university colleges, these individuals did not know the facilitator in advance.

\section{Communication on a digital platform}

The students said that it was easy to be direct and say what they truly meant in virtual meetings. One student (B) said: I know it was easier for me to say what I meant in the virtual meeting than it might have been if everyone sat around a table. Even if you look at each other on the screen, you do not look each other in the eyes.

\section{Facilitation and reflection}

The students appreciated that the conversation could be personal. One student $(\mathrm{N})$ said: I thought it was nice that the students used my name and that the facilitator made sure that all students participated. Because students from all three years of education participated, some of the students had less experience and felt they could not contribute as much as the others. One student (N) said: It must be accepted that some students will not understand questions and do not know what the facilitator is asking. Students emphasized that the role of the facilitator was important for the organization of IPL through digital platforms. The facilitator also plays a role in getting the participants to reflect interprofessionally.

\section{Discussion}

The main motivation for this project was encouraging healthcare students to learn to work together across professional boundaries before graduation. This idea is emphasized in public documents $[1,2,4,35]$. The use of a digital platform can help students from various professional backgrounds collaborate before they graduate, which is in line with the recommendations from these documents $[1,2,4]$. However, there may be different study conditions for IPL in different educational institutions. The digital tools available for collaborative learning may also differ [14].

Interprofessional collaborative learning

After the two virtual meetings in the IPL project, the students learned the importance of interprofessional collaboration. Nevertheless, these individuals still emphasized that they needed to learn more to become ready for collaborative practice after graduation.

The students in this study were from different professions and different cohorts. These differences might present a problem in some ways, but they might also be positive. Students in healthcare services meet different professions with different 
8

Interprofessional Learning

Vasset, Brynhildsenb, \& Kvilhaugsvik

Journal of Research in Interprofessional Practice and Education

Vol. 9.1

2019 amounts of work experience. These meetings could be considered as a way to prepare them to collaborate with any profession. It became clear through the analysis of the focus group interviews that students found it useful to learn together across first, second, and third cohorts, i.e., people with less or more professional experience than themselves. Therefore, including students from different cohorts in IPL can be positive. The students liked to hear students from other professions describe the responsibilities of their professions. They stated that they acquired a deeper insight into both their own and other roles and areas of responsibility through the IPL project. The participants described the roles of their own professions; nurses, for example, were described as the glue in organizations. This role has also been reported in a previous study, which describes nurses as the core of collaborative settings $[35,36]$.

Students also feel increased competence and confidence when responding to conflict after practising interprofessional communication. Based on the opportunity to get to know their colleagues, students recognize that they have different knowledge that can contribute to patient safety. With this concept as a background, it is important that students gain an understanding of other professions and their skills [11]. In this study, students were able to see that other professions could solve some challenges in a better way, and that the way other professions solve problems may not necessarily be better in all situations.

Interaction between the participants in this study can be understood in at least three different ways $[9,23]$. The interaction between the participants took place between students in the digital platform and in the focus groups. Interactions between different ways of thinking, knowledge, ideas, and arguments occurred between different student professions and different cohorts. Some participants from the first cohort in the study found it challenging to work across the academic years. Studies have raised the question of when it is appropriate for students to acquire knowledge of collaboration and IPL [26,27]. In this study, the first-year students emphasized that they felt somewhat inferior in communication with third-year students. However, only biomedical science students were from the first year of study, and the other participants were very interested and listened eagerly when the subjects of biomedical science were discussed. One way to understand this phenomenon might be that a technical profession that works with issues such as blood sampling and the quality assurance of laboratory tests is a small professional group that the others do not know very well. The third interaction took place between what is discussed in the group and the larger sociocultural context. The purpose for the professionals is to gain insight and knowledge of the working day of other professionals. Thus, respect, collaboration, and common goals for the patients are important.

\section{The use of digital platforms}

The students were familiar with virtual communication in private but were not used to communicating through virtual meetings in educational settings. The students and the facilitators used a digital platform to communicate with each other in the virtual meetings. The use of a digital platform was not problematic because both participants and facilitators knew the platform in advance. The main reason a digital 
9

Interprofessional Learning

Vasset, Brynhildsenb, \& Kvilhaugsvik

Journal of Research in Interprofessional Practice and Education Vol. 9.1 2019 platform was used for IPL in this model was that the three university colleges had few health and social education programs. Both geographic distance and logistical solutions would be difficult if the students had to conduct face-to-face meetings. There could also be economic challenges because it is expensive to travel. These challenges are in line with those in other studies [37]. Educational institutions must be creative in finding solutions to logistical challenges to IPL [12].

Research [18] emphasizes that there are no clear findings and experiences with virtual tools in education. That is, it is not clear whether using virtual tools has a positive or negative outcome. Other studies have shown that different learning activities through digital platforms lead to a better understanding of interprofessional collaboration $[17,12]$. Some students may be able to express themselves more strongly in virtual meetings, therefore learning better, while other students do not benefit from this form of meetings. One difference between physical meetings around a table and virtual meetings, according to some participants, was that it was easier to be direct and say what they meant in the virtual setting. Research emphasizes that this difference is an advantage [37]. Some students said that the virtual world felt safer, and some of the students could be more active in virtual meetings due to distance and anonymity. Several students emphasized the central role of the facilitator, who ensured that everyone received important messages and communicated with the others. The fact that the facilitator used the name of each student felt important. This idea is in line with a study [25] recommending that all students should experience success and receive feedback on what they do, giving them the opportunity to reflect on their own development and thus increase self-esteem.

A videotaped case, which displayed problematic interprofessional collaboration, was used in the IPL project. The participants emphasized that watching the film revealed the need for collaboration more clearly than reading a written case could have done, because non-verbal communication is more visible in a film than in a written text. Being able to see the content of the entire case, the participants obtained a clearer basis for reflection. Previous studies have emphasized that joint activity and discussion will lead to more participation and reflection on situations [19-23,37], which using a film allows.

This study revealed some practical prerequisites that could inhibit or promote communication through digital platforms. The lack of technical savvy and background noise (e.g. students chatting on the phone with friends while using the digital platform) during conversations may be challenges that inhibit interaction. These problems could easily be solved with simple clarifications in advance.

The facilitation of communication in digital platforms

Students described the role of the facilitator as important. The students reported that the meeting they each had with the facilitator before the project started was of great value and gave them some security. The facilitators need to ensure that all participants in the group are active and are encouraged to present their views and reflections. To succeed in introducing IPL between educational institutions, it is important to incorporate values and norms, such as common focus and equality in 
10

Interprofessional Learning

Vasset, Brynhildsenb, \& Kvilhaugsvik

Journal of Research in Interprofessional Practice and Education

Vol. 9.1

2019 dialogue. The results of this study point out that it was easier for some students to be direct and say what they meant in a virtual meeting than in a physical meeting. Students might "hide" slightly in the digital platform because they do not need to look others in the eye. This "hiding" is not necessarily an advantage in IPL. Students and employees should be equally honest and open to all collaborations. It is also crucial that the digital platform used in IPL is well known to all parties. All members must have a camera and a headset on their computer to participate fully in the communication process, and also to avoid introducing noise in the virtual meeting or exposing other group members to random passers-by.

The use of a digital platform in student learning may also be problematic. Weak network connection is an important matter, as is human failure, where some participants dominate, and others barely participate at all. It may, therefore, be wise to have a facilitator who leads, delegates, comments, and takes responsibility for the virtual conversation. Nevertheless, the facilitator must assess the situation and not take too much responsibility. Student reflection remains important in learning processes; students need to experience and discuss the cases to be able to evaluate different situations [24]. In this study, students had not previously reflected on what interprofessional collaboration can mean for patients. Participants' statements on this theme revealed that it is possible to learn to reflect on interprofessional collaborative situations through virtual collaborative meetings. Once the students have thought about the importance of collaboration for the patients, it will probably be easier for them to advocate interprofessional collaboration to ensure safe patient care after they graduate.

\section{Limitations}

Validity in qualitative research refers to the appropriateness of processes and data collection. The research question must be valid for the desired outcome, the methodology appropriate for answering the research question, the design valid for the methodology, the sampling and data analysis appropriate, and the results and conclusions valid for the sample and context [38]. To increase the validity of the results, the three researchers analyzed the data together, and the process was transparent. The first consideration is that there were relatively few participants in this study. Including more students might have added more information or other perspectives. Nevertheless, this study was in line with previous recommendations [30]. It is not the number of participants that determines validity but rather that the research question is properly defined.

In this study, saturation was achieved. However, none of the social education students agreed to participate in the focus group interviews, although these students did participate in the IPL project. Consequently, we cannot conclude that all participating students in the IPL project had a positive IPL experience in the digital platform. Informal discussions with the social education students, however, did not reveal any information beyond what was given in the focus groups.

\section{Conclusion}

The aim of the study was to explore student experiences with IPL mediated through 
11

Interprofessional Learning

Vasset, Brynhildsenb, \& Kvilhaugsvik

Journal of Research in Interprofessional Practice and Education

Vol. 9.1

2019 a digital platform with the aid of a facilitator who participated in the virtual meetings to ensure focus and equality in dialogue. In this study, the students were familiar with virtual communication and found it to be a good tool in IPL. The results show that students gained insight into their own professions and the professions of the other participants, as well as into the importance of interprofessional collaboration. This initiative, however, is just the start of collaborative practice readiness, and the students found that they needed more experience with IPL.

\section{Further research}

There is still a need for research on IPL in Norway. This study provides an indication of how IPL interactions through a digital platform can be conducted. Because many Norwegian campuses have few educational programs in health and social care, there is a need to explore IPL collaboration between educational institutions. Different forms of technology can be tested when physical encounters are difficult. Small-scale research studies with facilitators seem to work reasonably well. It will be interesting to investigate whether these studies can be scaled up to accommodate whole programs. In addition, the role of the facilitator in IPL should be investigated in depth.

\section{References}

1. World Health Organization. (1988). Learning together to work together for health. Geneva, $\mathrm{CH}$ : World Health Organization.

2. World Health Organization. (2009). Human factories in patient safety, in topics and tools. Geneva, $\mathrm{CH}$ : World Health Organization.

3. Solem, A., \& Hermandsgård, M. (2015). Fasilitering [Facilitation]. Oslo, NO: Gyldendal Akademisk.

4. White Paper, 13. (2011-2012). Utdanning for velferd. Samspill i praksis [Education for welfare. Interaction in practice]. Oslo, NO: Utdanningsdepartementet.

5. Dickinson, C., \& Carpenter, J. (2005). Contact is not enough: An inter-group perspective on stereotype change in interprofessional education. In Colyer, H. Helme, M., \& Jones, I. (Eds). The theory-practice relations in interprofessional education (pp 23-32). London, UK: Higher Educational Academy, Health Sciences \& Practice Network.

6. Allport, G.H. (1954). The nature of prejudice. New York, NY: Addison-Wesley.

7. Olenick, M., \& Allan, L.R. (2013, April). Faculty intent to engage in interprofessional education. Journal of Mulitdisciplinary Healthcare, 6, 149-151.

8. Aase, K. \& Testad, I. (2010). Første, annen, halvannen - hva med sikkerheten? I Aase, K Pasientsikkerhet - teori og praksis i helsevesenet [Patient safety - Theory and practice in health care]. Oslo, NO: Universitetsforlaget

9. CAIPE. (1997). Interprofessional education-A definition. London, UK: Centre for the Advancement of Interprofessional Education.

10. Barr, H. (1994). Perspectives on shared learned: A report from the review of shared learned. London, UK: CAIPE.

11. Shaw, I. (1995). Locally based shaded learned. London, UK: Avebury, Aldershot.

12. Vasset, F., Bergun, I.E., Inderhaug, H., \& Almås, S.H. (2014). Tverrprofesjonell e-læring som pedagogisk verktøy i helse- og sosialfagutdanninger [Interprofessional e-learning as an educational tool in health and social education]. Vård i Norden, 34(1), 19-23.

13. Mørch, A., \& Solheim, V. (2005). Integrert e-loering i bedriften: pedagogikk, teknologi, organisasjon [Integrated e-learning in the enterprise: education, technology, organization]. Oslo, NO: Unipub.

14. Miers, M., Clarke, B., Pollars, K., Ricksby, C., Thomas, J., \& Turtle, A. (2007). Online Interprofessional Care. The student experiences. Journal of Interprofessional Care, 21(5), 529-542.

15. Dirckinck-Holmfeld, L., \& Fibiger, B. (2002). Learning in virtual environments. Frederiksberg, DK: Samfundslitteratur.

16. Solomon P., Baptiste, H., \& Hall, P. (2010). Students' perceptions of interprofessional learning through facilitated online learning modules. Medical Teacher, 32(9), 312-398. 
12

Interprofessional Learning

Vasset, Brynhildsenb, \& Kvilhaugsvik
17. Cooper, H., Spencer-Dawe, E., \& McLean, E. (2005). Beginning the process of teamwork: Design, implementation and evaluation of an inter-professional education intervention for first year undergraduate students. Journal of Interprofessional Care, 19(5), 492-508.

18. Erstad, O. Søby, M. Kløvstad, V., \& Kristiansen, T. (2005). På vei mot digital kompetanse $i$ grunnopploeringen [Towards digital skills in basic education]. Oslo, NO: Universitetsforlaget.

19. Schøn, D. (1987). Educating the reflective practitioner: Toward a new design for teaching and learning in the professions. London, UK: Jossey-Bass.

20. Clark, P.G. (2009). Reflecting on reflection in interprofessional education: Implications for theory and practice. Journal of Interprofessional Care, 23(3), 213-223.

21. Pearson, P., Dickinson, C. Steven, A., \& Dawson, P. (2007). Towards a common goal: Developing practice-based interprofessional education in North East England. In Barr, H. (Ed.), Piloting interprofessional education: Four English case studies. Occasional Paper No. 8, (19-55). London, UK: The Higher Education Academy.

22. Wright, A., \& Hawkes, G., Baker, B., \& Lindquist, S. (2012). Reflections and unprompted observations by healthcare students of an interprofessional shadowing visit. Journal of Interprofessional Care, 26(4), 305-311.

23. Ødegård, A., \& Willumsen, E. (2016). Tverprofesjonelt samarbeid. Et samfunnsoppdrag [Interprofessional cooperation. A social assignment]. 2 utg. Oslo, NO: Universitetsforlaget.

24. Nilsen, S.R., Røising, H., \& Brynhildsen, S. (2012). Erfare, skrive, dele, diskutere og lære [Experience, write, share, discuss and learn]. Uniped, 35(2), 54-66.

25. Löfmark, A., \& Wikblad, K. (2001). Facilitating and obstucting factors for development of learning in clinical practice: A student perspective. Journal of Advanced Nursing, 34(1), 43-50.

26. Hayashi, T., Shinozaki, H., \& Makino, T. (2012). Changes in attitudes toward interprofessional health care terms and education in the first- and third-year undergraduate students. Journal of Interprofessional Care, 26(2), 100-107.

27. Almås, S.H., \& Vasset, F. (2015). Health and social care students pursuing different studies, and their written assignment from workshop and online interprofessional eduvation. Nordic Journal of Nursing Research, 0(0), 1-6.

28. Barr, H. Helme, M., \& D'Avray, L. (2016). Tverrprofesjonell utdanning innen helse- og sosialfag i Storbritania. I Tverrproffesjonelt samarbeid. [In Interprofessional collaboration] Willumesen, E. \& Ødegård, A. Oslo: Universitetsforlaget.

29. Polit, D., \& Back, C.T. (2012). Nursing research. Philadelphia, PA: Lippinott Williams and Wilkins.

30. Malterud, K. (2017). Kvalitative metoder $i$ medisinsk forskning [Qualitative methods in medical research]. Oslo, NO: Universitetsforlaget

31. Malterud, K. (2012). Fokusgrupper som forskningsmetode for medisin og helsefag [Focus groups as research method for medicine and health science]. Oslo, NO: Universitetsforlaget.

32. Giorgi, A. (1985). Sketch of a psychological phenomenological method. Phenomenology and psychological research: Essays. Pittsburg, PA: Duquesne University Press.

33. Giorgi, A. (2009). The descriptive phenomenological method in psychology: A modified Husserlian approach. Pittsburg, PA: Duquesne University Press.

34. Ethical Standard in Public Life. (Scotland), Act 2000 (asp7). https://www.legislation.gov.uk /asp/2000/7/contents

35. Orvik, A. (2015). Organisatorisk kompetanse [Organizational competence]. Oslo, NO: Universitetsforlaget.

36. Benner, P., Sutphen, M., Leonard, V., \& Day, L. (2010). A utdanne sykepleiere [To educate nurses]. Oslo, NO: Akribe.

37. McLoughlin, C., Patel, K.D., O'Callaghan, \& Reeves, S. (2018). The use of virtual communities of practice to improve interprofessional collaboration and education: Findings from an integrated interview. Journal of Interprofessional Care, 32(2), 136-142.
Journal of Research in Interprofessional Practice and Education

Vol. 9.1

2019 